\title{
Determinants of Inflation: A Case Study of Iran
}

\author{
Abbas Khandan ${ }^{1}$ \& Seyyed Mahmood Hosseini ${ }^{2}$ \\ ${ }^{1} \mathrm{PhD}$ in Economics, University of Siena, Italy. \\ ${ }^{2}$ Master in Economics, Ferdowsi University of Mashhad, Iran \\ Correspondence: Abbas Khandan, University of Siena, Italy.
}

Received: June 24, 2016

doi:10.11114/aef.v3i4.1760

\author{
Accepted: July 5, 2016 \\ Available online: July 22, 2016 \\ URL: http://dx.doi.org/10.11114/aef.v3i4.1760
}

\begin{abstract}
The study of causes of inflation has probably given rise to one of the most significant macroeconomic debates in the field of economics. The debates differ in their hypotheses, mainly due to a range of conventional views about the appropriate measure to control inflation and also due to disparity between developed and developing countries. We all know that inflation is related with an excessive growth in money supply; a view originally belongs to monetarists. However, this theory does not explain changes in growth of money supply and its main factors. In this paper we tried to answer this question through a system of simultaneous equations incorporating several variables based on various theories of inflation. Iran was also selected as case of study which has suffered high inflation in the last forty years. Results confirm that money is the main cause, but we found that governmental budget deficit through an increase in money supply also indirectly affect inflation. To explain public deficits it seems that structural problems in generating revenue are to be condemned.
\end{abstract}

Keywords: inflation, money supply, public deficits, structural problems, Iran

JEL: E3, E5, H6, O5

\section{Introduction}

Studying the causes of inflation in previous decades has given rise to one of the most significant macroeconomic debates in the field of economics. The debates differ in their hypotheses, mainly due to conventional views about appropriate measures to control inflation and differences between developed and developing countries. In general, causes of inflation in developed countries is broadly identified as growth of money supply. In developing countries, in contrast, inflation is not purely a monetary phenomenon. Factors typically related to fiscal imbalances, driving higher money growth and exchange rate depreciation, dominate the inflation process in developing countries. Looking at the inflation records around the world, shown in Figure (1), it can be concluded that economic theories have been successful in control of inflation. There are only few countries - Venezuela, Sudan, Syria, Belarus, Iran, and Mongolia still suffering from high inflation.

The reason of failure in these small number of countries is of the main interest. For this purpose, this paper takes Iran as case of study and investigates the main determinants of inflation in Iran. Iran, with a population of 78 million and a GDP of about US\$1280 billion in 2014 (current US dollars, Purchasing Price Parity) is the biggest economy among other oil-exporting countries in the Persian Gulf region and the second in the Middle East. Figure (2) presents the inflation rate indicating instable macroeconomic situation of Iran in previous four decades. It shows that Iran has experienced a high inflation in almost all years of previous four decades. The source of this high and enduring inflation might be attributed to event-filled current history of this country. The Islamic Revolution of 1979, the war with Iraq (1980-1986) imposed by Saddam Hussein and, finally, the recent sanctions are only a few to be named. Another reason refers to direct and significant role of government in this economy. Thirty-five percent of GDP is spent by the government on the public budget, which; this ratio will be about $60 \%$ if one also considers the budget of state-owned companies. Public deficits were often financed with central bank's help. Iran has experienced an average growth rate of 25 percent in monetary base and 27 percent liquidity during the last forty years. 


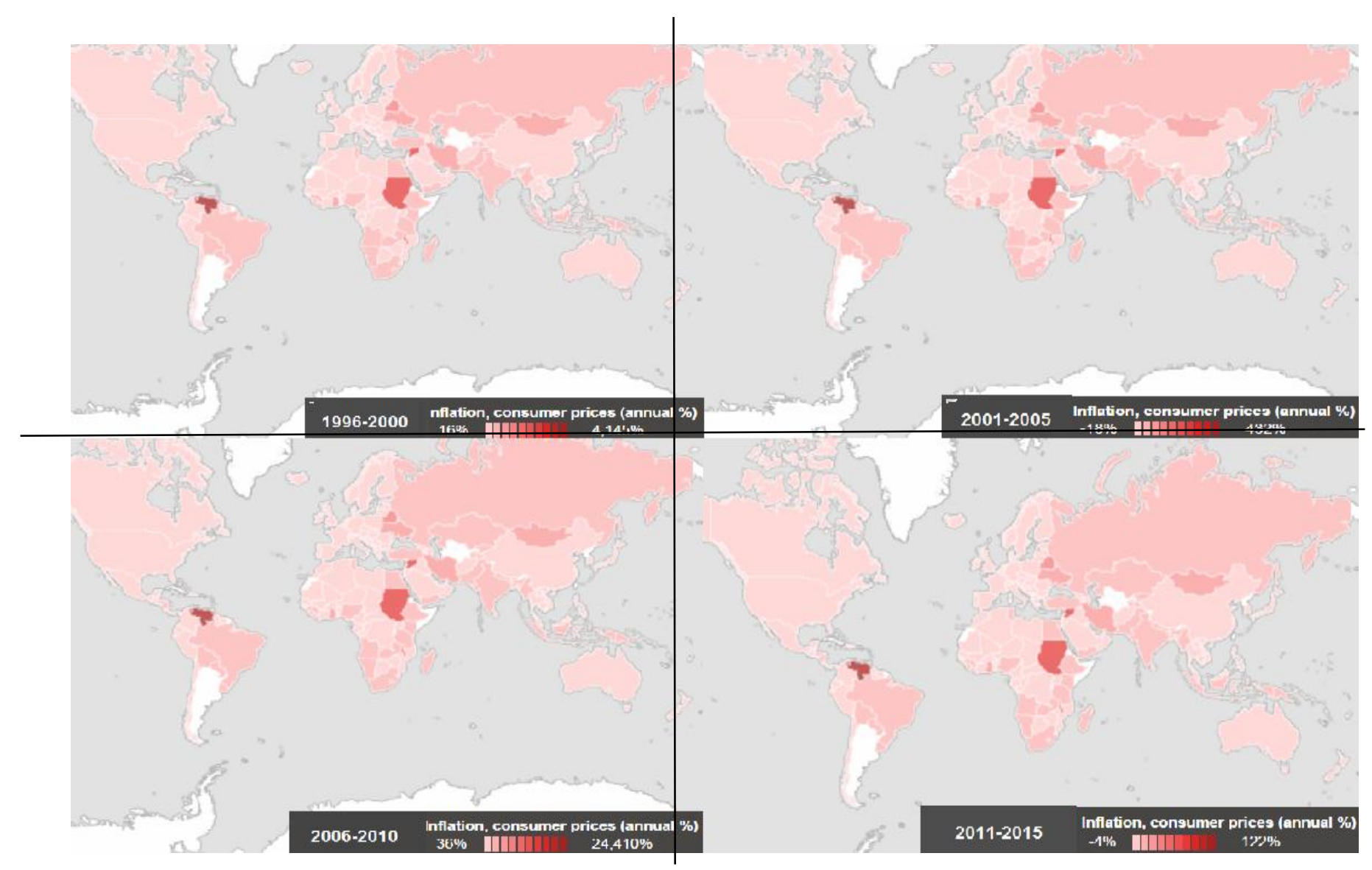

Figure (1). Inflation around the world, World Bank

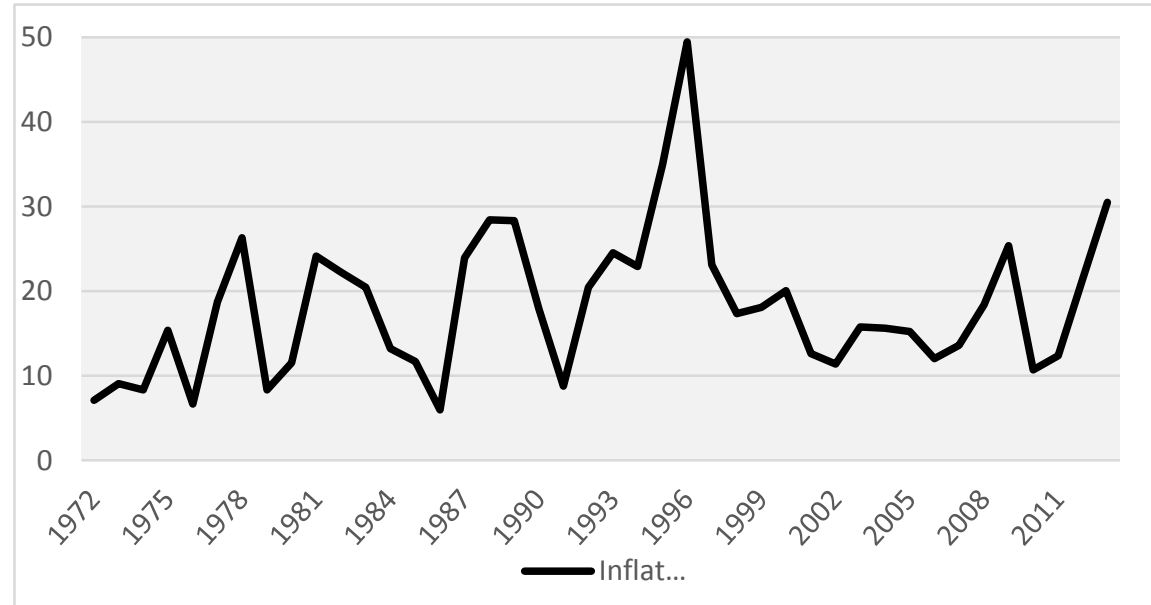

Figure (2). Inflation in Iran (1972-2013)

To explore determinants of inflation in Iran a sample period (1975-2012) is selected. Then, a system of simultaneous equation with 3SLS method is estimated. Before going to the empirical part, a brief review of the literature is presented in the next section. After that, the theoretical model and the empirical estimation are presented in section III. Section IV discusses the results. Section $\mathrm{V}$ concludes.

\section{Macroeconomic Theories of Inflation: Literature Review}

This section presents a brief review of the literature which is rampant with competing and complementary theories about the causes of inflation. The first, and in fact the oldest, theory is the Quantity Theory of Money. This theory asserts that changes in the general level of prices are determined primarily by changes in the quantity of money in circulation. The quantity theory of money was the core of 19th century classical monetary analysis. Irving Fisher 
(1876-1947) proposed his famous equation of exchange $\mathrm{M} \times \mathrm{V}=\mathrm{P} \times \mathrm{T}$ indicating that the whole money in circulation would be used in transactions with value as $\mathrm{P} \times \mathrm{T}$.

This and other equations like Cambridge cash balance equation belong to the time when the use of mathematics in neo-economic analysis was growing. Fisher and other neo-classical economists such as Arthur Cecil Pigou (1877-1959) of Cambridge, demonstrated that monetary control could be achieved in a fractional reserve-banking regime via control of an exogenously determined stock of high powered money.

Monetary Theory of Inflation is the second one which has roots in the above theory and the exchange equation of Fisher. Monetarism refers to the followers of M. Friedman (1912-2006). He stated that "only money matters", and, thus, monetary policy is more potent than fiscal policy in economic stabilization. According to the monetarists, money supply is the "dominate, though not exclusive" determinant of both the level of output and prices in the short run. But in the long run the production capacity is given ${ }^{1}$ and therefore it affects only on the level of prices. In sum, the monetarists emphasize on the role of money. Modern quantity theory offered by Milton Friedman indicate that "Inflation is always and everywhere a monetary phenomenon in the sense that it is and can be produced only by a more rapid increase in the quantity of money than in output (Friedman 1966, p.163).

John Maynard Keynes (1883-1946) and his followers raised the third theory known as Demand Pull Theory. This theory emphasizes on the increase in aggregate demand as the source of inflation. The aggregate demand consists of consumption, investment, government expenditure and net export. When the value of aggregate demand exceeds the value of aggregate supply at the full employment level, the inflationary gap arises. A larger gap between aggregate demand and aggregate supply leads to higher levels of inflation. However, Keynesians (Keynes and his followers) do not deny that even before reaching full employment, production factors can cause inflation.

According to demand-pull inflation theory, policies that cause a decline in each component of total demand are effective in reduction of demand pressure and inflation. For example a tax increase accompanied with or without controlling the volume of money reduce the total expenditure and, thus, can be effective to control inflation. In difficult conditions, e.g. hyperinflation during the war, where controlling the volume of money or decreasing the total expenditure may not be applicable, an increase in taxes is an alternative way to act directly against inflation.

The fourth is Cost-Push Theory which to explain inflation concentrates on the aggregate supply. Cost-push inflation is caused by negative external shocks, wage increases enforced by unions or, in general, increase in any other production factors. Cost-Push inflation takes place when, for example, the rise in money wages is more rapid than the labor's productivity growth. Labor unions' pressure for higher wages increases the cost of production. Employers, in turn, raise prices of their products. Higher prices spoils the higher wages and induces unions to demand still higher wages. In this way, the wage-cost spiral continues, thereby, leading to cost-push or wage-push inflation.

Various production sectors use products of other sectors as input. Therefore, wage increase in few sectors soon lead to inflationary rise in general prices of the entire economy. Even foreign inflation rising the price of imported goods leads to cost-push inflationary spiral. Another cause of Cost-Push inflation is profit-push inflation. Oligopolistic and monopolistic firms raise the price of their products to earn higher profits. The imperfect structure allow firms to make the price of their own products. Profit-push inflation is, therefore called administered-price inflation or price-push inflation. $^{2}$

About forty years ago, the Theory of Structural Inflation entered in economic discussion. Structuralists believe that the money stock is, in fact, responding to inflation rather than initiating it. The underlying factors are not to be found in monetary and fiscal policies but rather in the more basic weaknesses characteristics of developing countries. Consider agricultural sector as an example, growth elsewhere increase the income and the demand for food but, at the same time, supply decreases due to drawing away of labor forces from agriculture. The only way to stop prices from rising is to prevent the increase in excess demand for agricultural goods. Without extensive structural change, this means stopping economic growth. Therefore, inflation is in fact the cost of economic growth.

Macroeconomics in the 1970s is dominated by a revolutionary idea of Rational Expectations. ${ }^{3}$ Starting with the monetarist assumptions of continuous market clearing and imperfect information, the Theory of Rational Expectations argue that people do not consistently make the same forecasting errors as suggested in the adaptive expectations idea. Economic agents form their macroeconomic expectations "rationally". The rational expectations is based on all past and current relevant information available and, thus, is different from backward-looking or adaptive price expectations looking only to the past. According to the traditional monetarist approach from 1960s, the errors in price expectations

\footnotetext{
${ }^{1}$ See for example Beckerman (1992)

2 See Gordon (1977)

${ }^{3}$ See Lucas (1972), McCallum (1987), Hansen and Sargent (1980).
} 
were related to each other. But based on rational expectations theory, if monetary authorities announce a monetary stimulus in advance, people anticipate and expect a rise in prices. In this case, all economic agents index themselves with new prices in advance and, therefore, this fully anticipated monetary policy cannot have any real effect in economy even in the short-run as argued by monetarists. The Central Bank can affect the real output and employment only if it can find a way to create a "price surprise". Otherwise, "forward-looking" expectation adjustments of economic agents ensure that their preannounced policy fails.

Similarly, if a policymaker announces a disinflation policy in advance, it cannot reduce prices if people do not believe in that government will really carry it out. That is, in the new classical framework, price expectations are closely related to the policy credibility and reputation. According to monetarist and new classical economists, the growth in the money supply stems typically from the ongoing public sector deficits that are primarily financed by the Central Bank. In the "unpleasant monetarist framework" presented by Sargent and Wallace (1984), government budget is critical to understand the time path of inflation.

\section{Introducing Model and the Main Results}

To explain volatilities in inflation rate in Iran we use a system of simultaneous equations. The first equation is the demand for money. In Keynesian economy, demand for money is a function of total income and interest rate. Income increases people's transaction and, therefore, it is expected to be related positively with demand for money. Interest rate is the opportunity cost of keeping money out of bank in cash. It is expected to have a negative effect on demand for money. However, the situation in Iran is somehow different in the sense that there is no bond and the real rate of return from banking deposits is kept low by direct government intervention. People usually save their money by investing on real estates like houses.

Therefore, the rate of return in house market is a good proxy and more powerful than interest rate in explaining the changes in demand for money. Rate of return in these markets is unobservable, thus every person tries to estimate it using the whole information that he/she has at hand. We assume that people use expected inflation, measured by the average of inflation rate in last three years, as an indicator for unobservable rate of return in this market. That is:

$$
\left(\frac{M}{P}\right)=f\left(y_{t}, \pi_{t}\right)
$$

Where $\mathrm{M} / \mathrm{P}$ is the real money demand, yt is income and $\pi \mathrm{t}$ is the expected inflation rate. In logarithmic form we have:

$$
\log \left(\frac{M}{P}\right)=\alpha_{0}+\alpha_{1} \log \left(y_{t}\right)-\alpha_{2} \pi_{t}
$$

The money in circulation itself adjusts to changes in demand for money. Indicating the speed of adjustment by $\lambda$ :

$$
\Delta \log \left(\frac{M}{P}\right)_{t}=\lambda\left[\log \left(\frac{M}{P}\right)_{t}-\log \left(\frac{M}{P}\right)_{t-1}\right], \quad 0<\lambda<1
$$

Using these two formulas and by doing some algebra we can write:

$$
\log \left(P_{t}\right)=-\alpha_{0} \lambda-\alpha_{1} \lambda \log \left(y_{t}\right)+\alpha_{2} \lambda \pi_{t}+\log \left(M_{t}\right)+\log \left(\pi_{t}\right)
$$

Because in most of developing countries and Iran budget deficit is one of the main causes of increase in money supply, second equation of this system is going to explain changes in government budget. Real government expenditure is a function of real national income.

$$
\left(\frac{G}{P}\right)=f\left(y_{t}\right)
$$

Where $\mathrm{G} / \mathrm{p}$ is real government expenditure. We can write it in logarithmic form.

$$
\log \left(\frac{G}{P}\right)=g_{0}+g_{1} \log \left(y_{t}\right)
$$

Assuming the adjustment dynamics as below, with some calculation we would have the second equation as: 


$$
\begin{aligned}
& \Delta \log \left(\frac{G}{P}\right)_{t}=\delta\left[\log \left(\frac{G}{P}\right)_{t}-\log \left(\frac{G}{P}\right)_{t-1}\right], \quad 0<\delta<1 \\
& \log (G)_{t}=g_{0} \delta+g_{1} \delta \log (y)_{t}+(1-\delta) \log \left(\frac{G}{P}\right)_{t-1}+\log (P)_{t}
\end{aligned}
$$

Third equation represents changes in government earnings. Nominal government earnings positively relates to nominal national income.

$$
\begin{gathered}
R_{t}=f\left(P_{t} \times y_{t}\right) \\
\log (R)_{t}=t_{0}+t_{1}\left(\log (y)_{t}+\log (P)_{t}\right) \quad, t_{1}>0
\end{gathered}
$$

Again assuming dynamic of it as below, we end up with the third equation.

$$
\begin{gathered}
\Delta \log (R)_{t}=\beta\left[\log (R)_{t}-\log (R)_{t-1}\right], \quad 0<\beta<1 \\
\log (R)_{t}=t_{0} \beta+t_{1} \beta\left(\log (y)_{t}+\log (P)_{t}\right)+(1-\beta) \log (R)_{t-1}
\end{gathered}
$$

The fourth equation is the supply of money. Money supply is positively related to monetary base, $\mathrm{Mt}=\mathrm{mt} \times \mathrm{Ht}$. Where $\mathrm{Mt}$ stand for the money supplied in the year $\mathrm{t}$, and $\mathrm{Ht}$ is the monetary base. The monetary base is highly liquid money that consists of coins and paper money and commercial banks' reserves at the central bank. Changes in monetary base comes from public deficits or a change in in central bank international reserves.

$$
\Delta H_{t}=\Delta C G_{t}+\Delta O A_{t} \quad=>H_{t}-H_{t-1}=\Delta C G_{t}+\Delta O A_{t}
$$

Where $\Delta \mathrm{CGt}$ is the changes in government debt or budget deficit, and $\Delta \mathrm{OA}$ indicates the changes in central bank international reserves. Taking $\Delta \mathrm{OAt}+\mathrm{Ht}-1=\mathrm{Et}$ and $\Delta \mathrm{CGt}=\mathrm{Gt}-\mathrm{Rt}$, the supply of money can be written as below:

$$
M_{t}=m_{t} \times\left(G_{t}-R_{t}+E_{t}\right)
$$

Writing it in logarithmic form, we obtain the last equation:

\section{Empirical Modeling}

$$
\log (M)_{t}=k_{0}+\log (m)_{t}+k_{1} \log (G)_{t}-k_{2} \log (R)_{t}+k_{3} \log (E)_{t}
$$

The whole system including these four equations is presented below. The theoretical model introduced above is now summarized in one system of equations which must be estimated simultaneously.

$$
\left\{\begin{array}{l}
L R_{t}=c_{1}+c_{2}\left(L y_{t}+L P_{t}\right)+c_{3} L R_{t-1} \\
L G_{t}=c_{4}+c_{5} L y_{t}+c_{6} L G R_{t-1}+c_{7} L P_{t} \\
L M_{t}=c_{8}+c_{9} L G_{t}+c_{10} L R_{t}+c_{11} L E_{t} \\
L P_{t}=c_{12}+c_{13} L y_{t}+c_{14} L M_{t}+c_{15} L E P_{t}
\end{array}\right.
$$

Where LRt, and LGt are the logarithms of nominal government earning and expenditures respectively. The term LGRt stands as the logarithm of real government expenditures. In addition, the logarithms of money, national income and the CPI are shown by LMt, Lyt, and LPt respectively. And finally, LEPt is the logarithm of expected inflation.

The first equation representing government earnings is a function of total income, general prices and the earning of the previous year. The second equation shows government expenditures. It is a function of total income, general prices and real government expenditures in the previous year. The third equation represents the supply of money. It is a function of government expenditures, Government revenue and changes in international reserves of central bank. The last equation explains the level of prices which is the main interest here. It is a function of total income, supply of money and the expected inflation. This system of equation is estimated simultaneously with 3SLS method using time series data (1975-2012) of Iran. The data are collected from Iran's central bank which is available at www.tsd.cbi.ir. The results are shown in table (1) and (2). 
Table (1). Estimated Coefficients

\begin{tabular}{rrrrr}
\hline \hline & Coefficient & Std. Error & t-Statistic & Prob. \\
\hline \hline C(1) & 0.250513 & 0.125103 & 2.002458 & 0.0472 \\
C(2) & 0.103983 & 0.045104 & 2.305415 & 0.0226 \\
C(3) & 0.819986 & 0.086559 & 9.473137 & 0.0000 \\
C(4) & -2.336094 & 0.350423 & -6.666493 & 0.0000 \\
C(5) & 1.277730 & 0.124387 & 10.27224 & 0.0000 \\
C(6) & 0.198223 & 0.069781 & 2.840661 & 0.0052 \\
C(7) & -0.670619 & 0.103486 & -6.480281 & 0.0000 \\
C(8) & 0.179657 & 0.111472 & 1.611672 & 0.1093 \\
C(9) & -0.799704 & 0.376697 & -2.122940 & 0.0356 \\
C(10) & -0.628671 & 0.288821 & -2.176685 & 0.0312 \\
C(11) & 1.132739 & 0.131056 & 8.643170 & 0.0000 \\
C(12) & -3.432486 & 0.087309 & -39.31414 & 0.0000 \\
C(13) & -0.375270 & 0.064459 & -5.821853 & 0.0000 \\
C(14) & 0.457719 & 0.069227 & 6.611865 & 0.0000 \\
C(15) & 0.187926 & 0.057232 & 3.283555 & 0.0013 \\
\hline \hline
\end{tabular}

Table (2). Estimated Equations

\begin{tabular}{|c|c|c|c|}
\hline \multicolumn{4}{|c|}{$\begin{array}{l}\text { Equation: } L R T=C(1)+C(2)^{*}(L Y T+L P T)+C(3)^{*} L R T 1 \\
\text { Instruments: } L Y T \text { LPT LRT LGT LGR LMT LET LEPT C } \\
\text { Observations: } 38\end{array}$} \\
\hline R-squared & 0.992514 & Mean dependent var & 4.377974 \\
\hline Adjusted R-squared & 0.992086 & S.D. dependent var & 1.025618 \\
\hline S.E. of regression & 0.091241 & Sum squared resid & 0.291372 \\
\hline Durbin-Wats on stat & 1.721292 & & \\
\hline \multicolumn{4}{|c|}{$\begin{array}{l}\text { Equation: } L G T=C(4)+C(5)^{*} L Y T+C(6)^{*} L G R+C(7)^{*} L P T \\
\text { Instruments: LYT LPT LRT LGT LGR LMT LET LEPT C } \\
\text { Observations: } 38\end{array}$} \\
\hline R-squared & 0.996594 & Mean dependent var & 4.464944 \\
\hline Adjusted R-squared & 0.996294 & S.D. dependent var & 0.991542 \\
\hline S.E. of regression & 0.060364 & Sum squared resid & 0.123892 \\
\hline Durbin-Wats on stat & 1.034801 & & \\
\hline \multicolumn{4}{|c|}{$\begin{array}{l}\text { Equation: } L M T=C(8)+C(9)^{*} L G T-C(10)^{*} \mathrm{LRT}+\mathrm{C}(11)^{\star} \mathrm{LET} \\
\text { Instruments: LYT LPT LRT LGT LGR LMT LET LEPT C } \\
\text { Observations: } 38\end{array}$} \\
\hline R-squared & 0.985167 & Mean dependent var & 4.447463 \\
\hline Adjusted R-squared & 0.983858 & S.D. dependent var & 0.997144 \\
\hline S.E. of regression & 0.126688 & Sum squared resid & 0.545695 \\
\hline Durbin-Wats on stat & 0.375494 & & \\
\hline \multicolumn{4}{|c|}{$\begin{array}{l}\text { Equation: } L P T=C(12)-C(13)^{*} L Y T+C(14)^{*} L M T+C(15)^{*} \mathrm{LEPT} \\
\text { Instruments: } L Y T \text { LPT LRT LGT LGR LMT LET LEPT C } \\
\text { Observations: } 38\end{array}$} \\
\hline$R$-squared & 0.995648 & Mean dependent var & 0.726034 \\
\hline Adjusted R-squared & 0.995264 & S.D. dependent var & 0.861099 \\
\hline S.E. of regression & 0.059262 & Sum squared resid & 0.119408 \\
\hline Durbin-Watson stat & 0.484365 & & \\
\hline
\end{tabular}

\section{Discussing the Results}

All the results are represented in table (3). In the First equation both coefficients are of expected sign and significant which together with the constant explains 99 percent of variations in nominal government revenue. The main determinant of public revenue is its one year lagged variable i.e. government revenue one year before. Thus it can be concluded that nominal government revenue is an autoregressive variable AR(1) with a high coefficient of about eighty percent. The second variable is the nominal national earnings i.e. real national earnings times current prices. Since both variable are used in the form of natural logarithm, the coefficient of 0.1 is the elasticity of government revenue to national earnings. It shows that for example a 20 percent growth in national earnings, 5 percent real GDP growth and 15 percent inflation which has been very common in Iran, increases the governments' revenue by 2 percent. 
Table (3). Main results

\begin{tabular}{|c|c|}
\hline Equations & Goodness of fit \\
\hline $\begin{aligned} \mathrm{LR}_{\mathrm{t}} & =0.25+0.1\left(\mathrm{Ly}_{\mathrm{t}}+\mathrm{Lp}_{\mathrm{t}}\right)+0.82 \mathrm{LR}_{\mathrm{t}-1} \\
(0.12)(0.04) & (0.09)\end{aligned}$ & $\mathrm{R}^{2}=0.992$ \\
\hline $\begin{array}{l}\mathrm{LG}_{\mathrm{t}}=-2.3+1.27 \mathrm{Ly}_{\mathrm{t}}+0.2 \mathrm{LGR}_{\mathrm{t}-1}-0.67 \mathrm{LP}_{\mathrm{t}} \\
(0.35)(0.12) \quad(0.07)\end{array}$ & $R^{2}=0.996$ \\
\hline $\begin{aligned} \mathrm{LM}_{\mathrm{t}} & =0.18-0.8 \quad \mathrm{LG}_{\mathrm{t}}-0.63 \mathrm{LR}_{\mathrm{t}}+1.13 \mathrm{LE}_{\mathrm{t}} \\
(0.11)(0.38) & (0.29)\end{aligned}$ & $\mathrm{R}^{2}=0.985$ \\
\hline $\begin{aligned} \mathrm{LP}_{\mathrm{t}} & =-3.43-0.37 \mathrm{LY}_{\mathrm{t}}+0.45 \mathrm{LM}_{\mathrm{t}}+0.18 \mathrm{LEP}_{\mathrm{t}} \\
(0.09) & (0.06)\end{aligned}$ & $\mathrm{R}^{2}=0.995$ \\
\hline
\end{tabular}

The second equation is related to the other side of public budget which is government expenditures. The results again show that this variable is also autoregressive AR(1). In other words, government expenditures of one year before is one main predictor of its future amount. This is especially true for government spending on current goods and services. Results also show that real national income is another variable have a positive effect on government expenditures. The estimated elasticity is greater than one which shows a positive relation between growth in public budget and growth in total production of economy. The third variable in the equation is inflation which was assumed to have a positive effect on nominal government expenditures. However, the negative sign reject this hypothesis indicating that cutting the expenditure might be used as the first tool of contractionary policy to reduce inflation. These variables together explain 99.6 percent of variations in government expenditures.

Third equation represents the supply function of money. The results indicate that 98 percent of money supply can be explained by government expenditures, government earnings and changes in central bank reserves. As was mentioned in previous sections, LEt represents changes in foreign exchange reserves of central bank added to the monetary base. Central banks use these foreign exchange reserves as a mean to intervene and stabilize the exchange market. The result show that an increase in monetary base has a positive effect on the money supply. The elasticity is 1.13 and significant. Another variable determining money supply is government budget deficits. Governments in developing countries usually in order to finance their budget deficit borrow money from central bank. The obtained results somehow confirm this effect for Iran. Although the effect of government expenditures on money supply is negative and significant, according to estimated coefficients of the third equation the effect of government revenue is negative as expected. It indicates that government has covered its shortfall in tax collection by money borrowed from central bank. In other words, monetary policy of Iran was not an active policy in accordance with fiscal policies but it has been used passively to finance public deficits. Based on theories review before, it can be concluded that increase in money supply in Iran fits well with the theory of structural inflation. Accordingly, money supply is not the cause but a response to high inflation and structural problems of country.

The last equation is the main equation on which this paper is concentrated i.e. the main determinants of inflation in Iran. This equation has money supply, national income and expected inflation which all together explain 99 percent of variations in inflation of Iran. The results show that production has a negative and significant effect on inflation. This effect recall the famous Phillips curve. Expected inflation is the other variable which has got a positive and significant coefficient indicating that, according to the theory of rational expectations, forward-looking agents would not be surprised from or in fact expect the increase in money supply by government in response to structural problems of economy. The results show that changes in money supply is the main cause of inflation which confirms the impact of monetary theory of inflation beside other theories. The coefficient is significant and great. A ten percent growth in money supply raise an inflation of about 4.5 percent. The increase in money is related itself to government budget deficit. A ten percent deficit in revenue increases the money supply by 6.3 percent and derives up the inflation by almost three percent.

\section{Conclusion}

There are few countries which still suffer from high inflation. Iran is one of these countries which has experienced high inflation for a long period of about four decades. The significant role of government in Iran's economy together with eventful history of this country which is abundant with periods of economic or political turmoil like the Islamic revolution, the Iran-Iraq war and recent sanction make Iran an interesting case of study suitable for studding the effect of various factors and analyze various theories of inflation. These theories which were reviewed in the second section are the quantity theory of money, the monetary theory of inflation, the demand-pull theory, cost-push theory, theory of structural inflation and rational expectation. 
In this paper we tried to the main determinants of inflation using a system of simultaneous equations for the sample period of (1975-2012). The first and second equations are dedicated to changes in government earnings and expenditure. We expect that budget deficit is one of the main causes of increase in money supply and inflation in Iran. The third and fourth equations capture the variations in demand and supply side of money in order to determine the main causes of price inflation.

The results show that the total amount of money in circulation is one prominent determinant of inflation. This is in accordance with quantity theory of money and monetary theory of inflation. The supply of money is itself a function of budget deficits of government. However, the effect of shortfall in revenue is greater than government expenditure showing that money has not been used as policy in combination with public budget but is had been mostly a response to structural problems. This confirms the theory of structural inflation. Beside these factors, the expected inflation as expected has also a positive effect on inflation. According to theory of rational expectations, this means that forward-looking agents know this structural problems and in fact expect the increase in money supply by government.

\section{References}

Beckerman, P. (1992). The Economics of High Inflation, New York, St. Martin's Press.

Friedman, M. (1963). An economist's protest: columns in political economy, Princeton University Press.

Friedman, M., \& Anna, J. S. (1963). A Monetary History of the United States, 1867-1960, Princeton University Press.

Goodfriend, M. (1997). A Framework for the Analysis of Moderate Inflations, Journal of Monetary Economics, 39(1). http://dx.doi.org/10.1016/S0304-3932(97)00003-2

Gordon, J. R. (1977). The Theory of Domestic Inflation; Journal of Economic Review, 67(1), 128-134.

Hansen, L. P., \& Thomas, J. S. (1980). Formulating and estimating dynamic linear rational expectations models, Journal of Economic Dynamics and Control, $\quad$ Elsevier, 2(1), 7-46. http://dx.doi.org/10.1016/0165-1889(80)90049-4

Kirkpatrick, C., \& Nixon, F. (1976). The Origins of Inflation in Less Developed Countries: A Selective review, Inflation in Open Economics, M. Parkin and G. Zis (eds). Manchester University Press, 126-74.

Lucas, R. (1972). Expectations and the Neutrality of Money, Journal of Economic Theory, 4, $103-124$. http://dx.doi.org/10.1016/0022-0531(72)90142-1

McCallum, T. B. (1987). Inflation: Theory and Evidence, New York, American National Bureau of Economic Research, Working Paper, 2312.

Sargent, J. T., \& Neil, W. (1984). Some unpleasant monetarist arithmetic, Monetarism in United Kingdom, 15-41

Totonchi, J. (2011). Macroeconomic Theories of Inflation; International Conference on Economics and Finance Research.

\section{(cc) BY}

This work is licensed under a Creative Commons Attribution 3.0 License. 